Lockdown farmers markets in Bengaluru: Direct marketing activities and potential for rural-urban linkages in the food system

\author{
Neda Yousefian ${ }^{\text {a* }}$ \\ Georg-August-Universität Göttingen
}

SPECIAL ISSUE COSPONSORED BY INFAS: THE IMPACT OF COVID-19 ON FOOD SYSTEMS

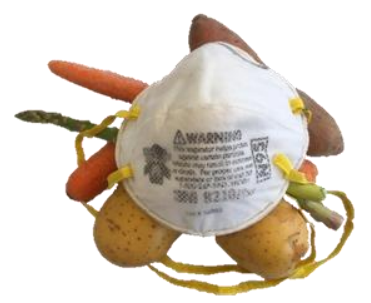

Inter-institutional

Network for

Food and Agricultural Sustainability

\author{
M. Soubadra Devy b \\ Ashoka Trust for Research in Ecology and the Environment (ATREE)
}

K. Geetha ${ }^{c}$

University of Agricultural Sciences GKWK, Bangalore

Christoph Dittrich d

Georg-August-Universität Göttingen

Submitted September 29, 2020 / Revised November 24 and December 21, 2020 /

Accepted December 24, 2020 / Published online March 23, 2021

Citation: Yousefian, N., Soubadra Devy, M., Geetha, K., \& Dittrich, C. (2021). Lockdown

farmers markets in Bengaluru: Direct marketing activities and potential for rural-urban linkages

in the food system. Journal of Agriculture, Food Systems, and Community Development, 10(2), 105-121.

https://doi.org/10.5304/jafscd.2021.102.034

Copyright (C) 2021 by the Authors. Published by the Lyson Center for Civic Agriculture and Food Systems. Open access under CC-BY license.

\begin{abstract}
Rural-urban linkages are vital elements in a sustainable food system. As the COVID-19 pandemic unfolded, supply chains were disrupted

a * Corresponding author: Neda Yousefian, Doctoral researcher, Georg-August-Universität Göttingen, Institute of Geography, Department of Human Geography, Goldschmidtstr. 5, 37077 Göttingen, Germany; neda.yousefian@uni-goettingen.de

b M. Soubadra Devy, PhD, Senior Fellow, Suri Sehgal Centre for Biodiversity and Conservation, Ashoka Trust for Research in Ecology and the Environment (ATREE), Royal Enclave, Sriramapura, Jakkur Post, Bangalore, 560064, India; soubadra@atree.org
\end{abstract}

${ }^{c}$ Dr. K. Geetha, Professor and Scheme Head AICRP-Home Science (Food \& Nutrition), University of Agricultural Sciences GKWK, Bangalore, 560065, India; dr.geethak@yahoo.com and fear of infection impacted food shopping decisions, pushing consumers to seek local and safer options for procuring fresh produce. Direct marketing arose as a promising alternative for both consumers and producers. We undertook a

d Prof. Dr. Christoph Dittrich, Institute of Geography, Head of Department of Human Geography, Georg-AugustUniversität Göttingen, Goldschmidtstr. 5, 37077 Göttingen, Germany; Christoph.dittrich@geo.uni-goettingen.de

\section{Funding Disclosure}

The author(s) gratefully acknowledge the financial support provided by the German Research Foundation (DFG), grant number DI 709/2-2, through the Research Unit FOR2432/2 Social-Ecological Systems in the Indian Rural-Urban Interface: Functions, Scales and Dynamics of Transition. We are also thankful for the cooperation and infrastructural support of our partners at the University of Agricultural Sciences, Bangalore. 
study in Bengaluru, India, in order to understand what direct marketing activities have unfolded with the COVID-19 pandemic. Media reports highlighted the plight of farmers struggling to market their harvest during lockdown as well as the farm to fork initiatives and lockdown farmers markets that have been created as a response. We see this moment as an opportunity to develop Bengaluru's food system to be more sustainable, specifically through the City Region Food System framework. This study conducted online and telephone surveys with both consumers and producers in Bengaluru to explore the elements of supply and demand that have fostered and hindered direct marketing schemes. We found that consumers are interested in sourcing fruits and vegetables directly from farmers, but communication and logistics between consumers and producers are major hindrances. Although producers are diversifying their marketing strategies, they need to be implemented at economically viable scales to ensure long-term success. We find that the role of technology, specifically messaging apps, can streamline direct marketing activities and remove the barriers that currently hamper ruralurban linkages. Furthermore, existing community and farmer organizations have the size and scale to make direct marketing schemes a worthy endeavor for both consumers and producers.

\section{Keywords}

City Region Food System, COVID-19, Pandemic, Direct Marketing, Farmer Producer Organization, Resident Welfare Association, Rural-Urban Linkages, Supply Chains

\section{Introduction}

The COVID-19 pandemic shocked food systems around the world, testing resilience and revealing frailties in the networks that currently connect billions of people to their food. Cities are hotspots of the COVID-19 pandemic worldwide (Mishra, Gayen, \& Haque, 2020; Muggah \& Florida, 2020) and the lockdowns implemented to curb the spread of the coronavirus exposed weaknesses and vulnerabilities in city functions, especially in local food systems. Market closures and transportation disruptions forced farmers from the peri-urban and rural areas to reach out directly to urban consumers (Biswas, 2020). The imperative for cities to build resilient, sustainable food systems is more apparent than ever before.

This paper examines changes in the food system during the COVID-19 pandemic lockdown (March to June 2020) in the megacity of Bengaluru, in southern India. The motivation for this study is based on the many media reports on emerging farm-to-fork networks in Bengaluru (Abraham, 2020; Aggarwal, 2020; K. R., 2020a; Kappan, 2020; Karelia, 2020; Rao, 2020). We seek to understand the extent of these networks as well as the barriers preventing them from growing. We use the City Region Food System framework (Carey \& Dubbeling, 2017) as our food systems lens point of reference. This framework has the scope to holistically assess the food system and offers practical tools for food system transformation. To better understand the changes that occurred in Bengaluru's food system and the potential for community-based organizations to become more closely linked in the food system, we surveyed urban consumers, resident welfare associations (RWAs), and rural farmer producer organizations (FPOs).

The research questions guiding our work were:

- Has the COVID-19 pandemic led to a rise in direct marketing between urban consumers and local producers?

- Can existing community organizations, specifically RWAs and FPOs, collaborate in neighborhoods to facilitate direct marketing schemes?

- Can the direct procurement practices of urban consumers developed during lockdown be sustained?

To the best of our knowledge there have been no studies on direct marketing linkages between RWAs and FPOs in India. This paper seeks to address this gap by exploring direct marketing activities that occurred during the COVID-19 lockdown and suggesting ways in which these bourgeoning rural-urban linkages in the local food system can be strengthened. 


\section{Literature Review}

\section{City Region Food System}

The City Region Food System (CRFS) framework is a food systems approach that comprehensively engages with the complexity of sustainability in urban food systems. It is context-dependent and includes other food systems approaches in its application, including short food supply chains, rural-urban linkages, and alternative food networks (Blay-Palmer, Santini, Dubbeling, Renting, Taguchi, \& Giordano, 2018). The CRFS has gained prominence in urban food policy due to the international declarations and agreements created through the Milan Urban Food Policy Pact, the City Region Food Systems Alliance and the Seoul Declaration (FAO, 2018). The CRFS puts forth the crucial need to elevate the ecological, socioeconomic, and governance linkages between urban centers and surrounding rural areas to create a more sustainable food system (Dubbeling, Renting, \& Hoekstra, 2015).

One component of the CRFS framework is Short Food Supply Chains (SFSCs) (Jennings, Cottee, Curtis, \& Miller, 2015). SFSCs are direct connections between producers and consumers that are based on trust and two-way communication; they have a short geographical distance between production and consumption and involve only one, or preferably no, intermediary (Proctor \& Berdegué, 2016). The CRFS framework also includes rural-urban linkages, which enhance livelihoods, improve nutrition, and provide net environmental benefits for people residing in urban, periurban, and rural localities (Berdegué, Proctor, \& Cazzuffi, 2014; Blay-Palmer et al., 2018; Jennings et al., 2015; Proctor \& Berdegué, 2016). Alternative food networks, such as community supported agriculture (CSA), are another way for producers and consumers to directly connect. While there are various organizational structures to CSAs, in most cases the consumers pay a monthly membership fee to regularly receive fresh farm products. In this arrangement everyone involved shares the risks and rewards in agriculture (Moore, McCarthy, Byrne, \& Ward, 2014).

The CRFS approach takes the above-mentioned food system components and seeks to embed them into a larger analysis of the flows and scales of operations within the rural to urban food systems, thereby effectively influencing food policy and directing research towards sustainability and resilience (Blay-Palmer et al., 2018).

\section{Direct Marketing and the CRFS Framework}

In this paper we use the CRFS framework to examine how urban consumers, RWAs, and FPOs engage in the local food system. Although RWAs are not primarily tasked with procuring food for their residents, some RWAs have engaged with farmers to sell fresh produce to their residents, both before and during the COVID-19 lockdown. Likewise, while FPOs mainly work with government marketing channels, recent agricultural policies have encouraged contracts between FPOs and private bulk buyers (Nikam \& Kale, 2020). We describe RWAs and FPOs in more detail in the final paragraphs of this section. Many researchers assert that farm to market linkages and the strengthening of India's FPOs are imperative in transforming local food systems (Chand, 2012; Kumar, Padhee, \& Kumar, 2020).

Diversifying marketing outlets bolsters the overall resilience of the food system (MoraguesFaus, Marsden, Adlerová, \& Hausmanová, 2020; Worstell \& Green, 2017). The dependence of urban consumers on large supermarkets makes them vulnerable to price hikes and shortages, as was seen in the early days of the COVID-19 pandemic (Bengaluru Bureau, 2020). Similarly, the dependence of producers on a single or very few marketing channels increases their vulnerability to shocks and crises, which makes the food system less resilient. Redundancies in the food system counterbalance this dependency and reduce the vulnerability of both producers and consumers (Sukhwani, Deshkar, \& Shaw, 2020). Using the CRFS framework, we seek to understand if RWA and FPO linkages can become an alternative marketing channel that make the food system more resilient to shocks and crises.

\section{Food System in India}

The Government of India (GOI) has enacted legislation to strengthen the position of Indian farmers, perhaps most notably with the Agricultural Pro- 
duce Marketing Committee (APMC) Acts. These Acts mandate the creation of special markets, referred to as APMC markets or mandis, where farmers sell their produce through more transparent processes that include open auctions and fair payments (Chand, 2012). The Model Act of 2003 was an amendment to the APMC that created private and cooperative markets where farmers engage in direct marketing (Chand, 2012).

In July 2020 the GOI notified two national ordinances, The Farmers' Produce Trade and Commerce Ordinance and The Farmers Agreement on Price Assurance and Farm Services Ordinance (Mint, 2020). These ordinances allow farmers to sell directly to bulk buyers, outside of the jurisdiction of the APMC markets and throughout the country through barrier-free trading (Babu \& Dassani, 2020). In these new ordinances, farmers are also being pushed to utilize e-marketing platforms (Chintala \& Mani, 2020). However, many farmers and farmer organizations criticize these new ordinances, arguing that the Minimum Support Price and the role of the APMCs are being diluted, exposing farmers to more risk (Balaji, 2020).

While the APMCs and the associated amendments are well intentioned, it is important to note that in India "the channels for marketing of agricultural produce remain long and fragmented" (Chand, 2012, p. 55). In Bengaluru, farmers typically sell through three channels: Horticultural Producers' Cooperative Marketing and Processing Society (HOPCOMS) markets, APMCs, and farmer networks. HOPCOMS is a cooperative that has retail spaces throughout Bengaluru; its operations bring over 70 tons of vegetables per day to the city (Sami \& Surie, 2017). Alternative food networks (e.g. organic food shops) do exist, but cater to urban middle-class consumers (Erler \& Dittrich, 2020). The number of intermediaries in the value chain varies depending on the marketing channel. On average, Chand (2012) calculates that between four to six intermediaries are involved before a product reaches the consumer, with little to no value being added. Trebbin (2014) estimates this number to be higher, with up to eight intermediaries, "from village-level consolidators, transporters, wholesalers and commission agents in state-regulated government markets (APMC markets) to retailers" (p. 39) involved in vegetable marketing chains, resulting in prices inflating 200$300 \%$ more than what the farmer earns. This great loss of potential income to farmers is a major incentive for farmers to pursue direct marketing channels and retain a greater share of the value chain (Special Correspondent, 2020c).

\section{Food System in India during the COVID-19 Pandemic}

On March 24, 2020, the GOI announced a 21-day nationwide lockdown, providing only four hours of warning (Gettleman \& Schultz, 2020). This lack of forewarning resulted in panic buying, the mass migration of informal laborers from cities back to villages, and disruptions in the transportation of essential goods, including fresh fruits and vegetables (Bengaluru Bureau, 2020; Bharadwaj, 2020a; Frayer \& Pathak, 2020). The lockdown was extended three times, becoming, at the time, one of the longest coronavirus lockdowns in the world. On June 8, after 75 days, India began a phased reopening (Kumar, D., 2020).

The lockdown began at the peak of harvest for the rabi season (winter) crops, forcing farmers to harvest and market their produce in the face of unprecedented challenges: barriers in transportation (road closures, travel permit requirements, police checkpoints), market closures or limited hours of operation, and fewer laborers for both field and market operations due to the mass migration of daily wage earners (Abhishek et al., 2020; Bharadwaj, 2020b; Ceballos, Kannan, \& Kramer, 2020; Raj, 2020). Consumer interest in food production grew, both in terms of home gardening and direct purchasing activities (Devy \& Casiker, 2020; Kumar, B. S. S., 2020b). RWAs, FPOs, NGOs, and government agencies worked together to create opportunities for direct marketing, mobile marketing, and online marketing schemes, thus benefiting both farmers and consumers (Abraham, 2020; K. R., 2020a; K. R., 2020b; Special Correspondent, 2020a; Sukhwani et al., 2020). For example, 'lockdown farmers markets' on social media were created to connect producers with consumers (Aggarwal, 2020; Joshi, 2020; Karelia, 2020; Kumar, B. S. S., 2020a; Narayanan \& Saha, 
2020; Rao, 2020; Wangchuk, 2020). The number of food shopping apps also increased during the lockdown (Bhatt, 2020; Kappan, 2020; Nainar, 2020; Special Correspondent, 2020b).

\section{Resident Welfare Associations and Farmer Producer Organizations}

RWAs are registered community groups that are made of elected volunteers who advocate for infrastructure and public services in their respective neighborhoods. While they have no official governmental power, they are often active in upholding local bylaws and can even hold political sway in local elections (Harriss, 2010). They also tend to cater to the needs of the middle and upper classes (Mahadevia, Bhatia, \& Bhatt, 2016). During the lockdown, many RWAs engaged with farmers and FPOs to enable direct marketing to their residents and coordinate distribution of donated food packages to needy families in their areas (K. R., 2020a).

FPOs are registered groups of geographically clustered smallholder farmers who purchase inputs and market their products collectively. Smallholders account for $86 \%$ of all Indian farmers (Government of India, 2019), and the development of FPOs has given them better access to both inputs and markets. Bisht, Rana, and Pal Ahlawat (2020) undertook a study on strategies for bringing these 126 million smallholder farmers into the food system in an economically and environmentally sustainable way. Half of the households in their study of 1,000 farmer households preferred forming farmer collectives to meet the demands of urban consumers.

In 2002, the GOI amended the Companies Act of 1956 to allow for the creation of FPOs. FPOs operate as cooperatives in their production, postharvest, and marketing activities (Chand, 2012). The legislation for FPOs was created to boost smallholder farmers' participation in agricultural value chains (Trebbin \& Hassler, 2012). A study conducted in 2019 determined that between January 1, 2003, and March 31, 2019, a total of 7,374 FPOs were registered nationwide (Neti, Govil, \& Rao, 2019). In Bengaluru, there are 15 officially registered FPOs spread across rural and urban areas (National Bank for Agriculture and
Rural Development [NABARD], 2020; Small Farmers' Agri-Business Consortium [SFAC], 2016). Their organizational structure can be best described as a "hybrid between private companies and cooperative societies" (Trebbin, 2014, p. 39). FPOs are owned and operated by the member farmers. They receive financial assistance from the government or from donor organizations and their management is often done by professionals (Trebbin \& Hassler, 2012).

In the wake of the COVID-19 lockdown, some FPOs have been supported through the Small Farmers' Agri-Business Consortium (SFAC). The SFAC is a government program, supported by the Ministry of Agriculture and Farmers Welfare, that assists FPOs in marketing their products through such initiatives as the use of online portals to manage the supply, demand, and logistics of delivery, the creation of a WhatsApp group with pan-Indian buyers, and the facilitation of direct market linkages with large buyers, retailers, and RWAs (SFAC, 2020). The disruptions in marketing caused by the lockdown affected the operations of all FPOs to varying degrees, however, some demonstrated greater resilience than others and adapted to the situation by engaging in direct marketing to urban consumers (D, 2020; Special Correspondent, 2020c).

\section{Research Methods}

In this study, we investigate how the COVID-19 pandemic led to a rise in direct marketing between urban middle-class consumers and local producers. We focus on urban middle-class consumers because they constitute a significant demographic with strong purchasing power, and they are a targetable population for an online survey. We are specifically interested in the marketing and consumption of fruits and vegetables because of the high volume of regional production supplying local markets (Sami \& Surie, 2017). Our regional focus is Bengaluru Urban which includes the megacity of Bengaluru, the capital of Karnataka state, and the surrounding peri-urban areas (Government of Karnataka, n.d.). Bengaluru Urban has an estimated population of 12 million inhabitants, making it the third largest city in India after Mumbai and Delhi (World Population Review, 2021). 
Online Survey

The online survey was designed using LimeSurvey Version 3.22.17+200525 and was posted online to 12 Bengaluru-based Facebook groups. These groups include Bengaluru resident welfare groups, groups focused on the topics of food and/or gardening, and groups that were created during the lockdown to connect farmers with consumers (see Appendix A). The post with the link to the survey was shared twice, once on July 15 and once on August 5, 2020. The survey was also distributed twice through the email listserv of the Bengalurubased not-for-profit organization Ashoka Trust for Research in Ecology and the Environment (ATREE). We used a frameless sampling strategy in survey distribution (Fielding, Lee, \& Blank, 2016). We then used post stratifying methods to select responses exclusively from Bengaluru Urban residents. The survey was designed so that participants remain anonymous; however, participants had to identify their ward and PIN locations to ensure that all respondents reside within Bengaluru Urban. Data analysis was done using Excel 2019 MSO and Stata 13.

In total we received 236 responses, of which 125 were complete and valid, making the survey completion rate $53 \%$. Of these 125 responses, eight respondents were located outside of Bengaluru Urban and were thus excluded from our study. We use 117 complete responses for our analysis.

\section{$R W A$ Survey}

Two online sources, the Bengaluru government website (BBMP, 2016) and the Bengaluru Governance Observatory website (Bengaluru Governance Observatory, 2020), were used to compile a list of 865 RWAs in Bengaluru Urban. We randomly selected 320 RWAs for a telephone-based survey. Of the 320 RWAs contacted, 117 RWA members agreed to participate in the survey. Of the 203 RWAs that did not participate, 158 RWA phone numbers (49\%) were no longer functional and 45 RWAs declined to participate.

\section{FPO Survey}

We compiled a list of 22 FPOs registered in Bengaluru Urban and Rural from three sources, the Small Farmers' Agri-Business Consortium (SFAC, 2016), the National Bank for Agriculture and Rural Development (NABARD, 2020) and the KrishiJagran website (Krishi Jagran, n.d.). Of these, we were able to conduct our survey with six FPOs by phone. We sent emails to seven FPOs who were not reachable by telephone and one responded with their updated contact information. Because one of the surveyed FPOs does not operate in Bengaluru we did not include them in our analysis; thus, our sample size for the FPO survey is six.

\section{Results}

The results are presented in three parts based on the three surveys conducted. We begin with reviewing the results of the online survey, followed by the RWA and FPO surveys. Map 1 shows Bengaluru Urban boundaries and the distribution of respondents to the online and RWA surveys.

\section{Online Survey}

The online survey addressed how the COVID-19 lockdown in Bengaluru impacted various aspects of food procurement and consumption. It included the following five sections: food shopping, consumption, direct purchasing from farmers, home gardening, and food safety. This paper and the results presented below are based on the first three sections of the survey. Table 1 presents the demographic results.

Based on the results in Table 1, we see that our survey reached an almost equal percentage of males and females. In terms of education and income, $92.3 \%$ of our respondents are highly educated, with $56.4 \%$ belonging to the upper and upper middle classes, earning more than 40,000 Rupees per month (543 USD). Nearly $70 \%$ of respondents are currently employed.

\section{Food Shopping Habits}

The first section of the online survey addressed food shopping habits and the changes that occurred as a result of the lockdown. Table 2 shows where respondents sourced their fruits and vegetables before and during the lockdown.

We asked respondents to clarify exactly how they contact farmers for direct purchasing. We found that the lockdown had an impact on the 
Map 1. Distribution of Online and Resident Welfare Association (RWA) Survey Respondents

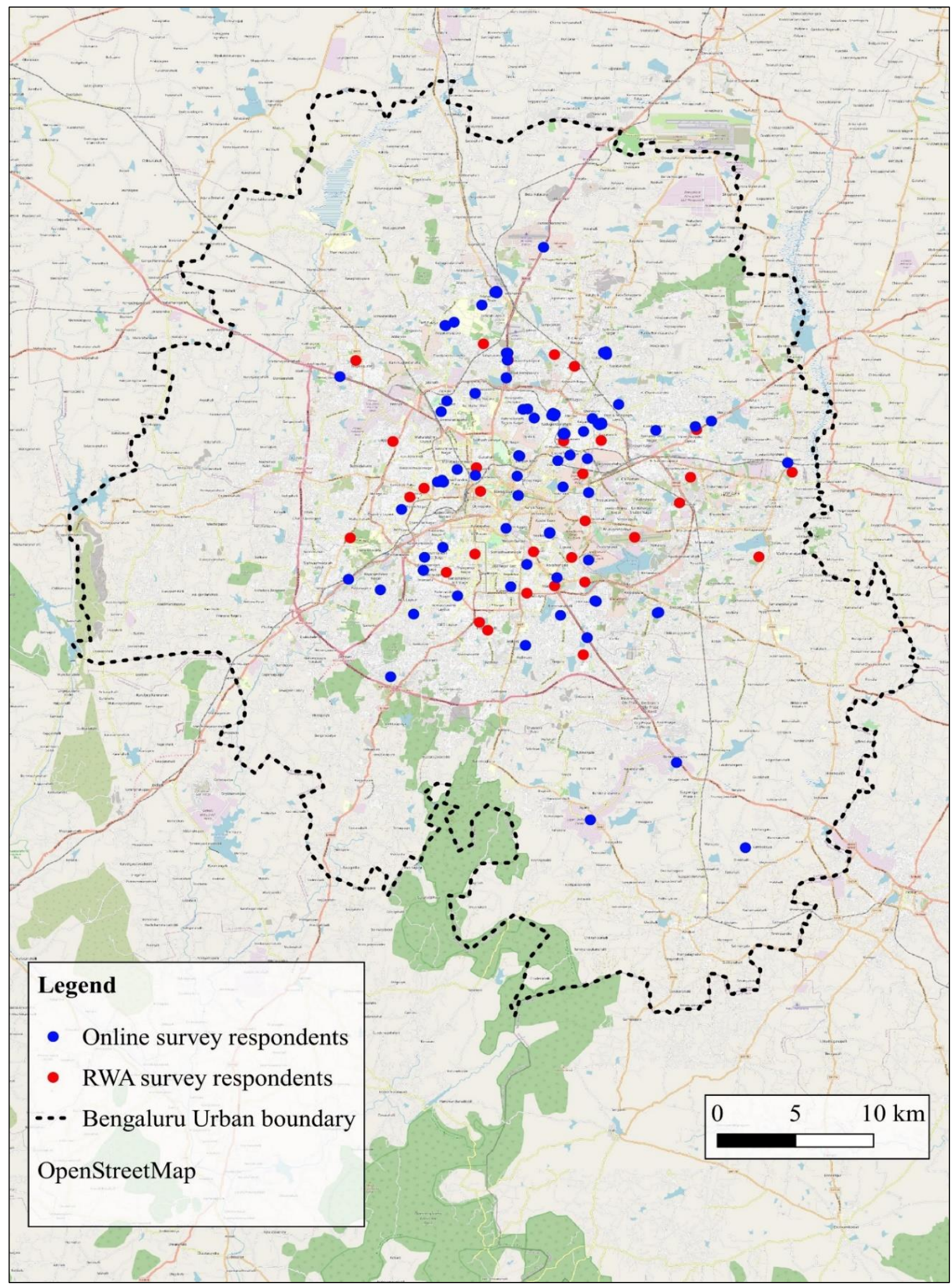


mode of contact between consumers and producers (Table 3 ).

Social media and food shopping apps When asked if they had joined any social media groups in order to purchase fruits or vegetables directly from farmers, 15 of 117 respondents said that they had. Of these, the majority used WhatsApp (10.3\%), with Facebook (3.4\%) and Instagram (2.6\%) being the other platforms used. Twitter $(0 \%)$ was not used by any of the participants.

The use of food shopping apps to purchase fruits or vegetables directly from farmers was also quite low, with only nine of 117 respondents saying that they had used an app for this purpose. The Big Basket app was used by three respondents. Two respondents used WhatsApp for this purpose. Zomato, Swiggy, Dunzo, Agrimitra, and KSMDC apps were each selected once, while the Farmer near me, $\mathrm{MyBy}$, and Sabjee apps were not used.

\section{Direct purchasing}

In order to understand consumer attitudes towards direct purchasing, we asked respondents to consider six factors as either positive or negative aspects of directly purchasing produce from farmers. The six factors are: variety of produce, locally produced, freshness,
Table 1. Demographics of Online Survey Respondents $(N=117)$

\begin{tabular}{|c|c|c|}
\hline Category & & Percentage \\
\hline \multirow[t]{3}{*}{ Gender } & Female & $44.4 \%$ \\
\hline & Male & $50.4 \%$ \\
\hline & Gender not specified & $5.1 \%$ \\
\hline \multirow[t]{4}{*}{ Education } & High school certificate & $2.6 \%$ \\
\hline & Diploma/PUC & $5.1 \%$ \\
\hline & Graduate & $60.7 \%$ \\
\hline & Profession or Honors & $31.6 \%$ \\
\hline \multirow[t]{8}{*}{ Occupation } & Salaried employment, private sector & $60.7 \%$ \\
\hline & Salaried employment, public sector & $7.7 \%$ \\
\hline & Student & $13.7 \%$ \\
\hline & Entrepreneur, self-employed & $0.8 \%$ \\
\hline & Housewife/Househusband & $5.1 \%$ \\
\hline & Unemployed & $6.0 \%$ \\
\hline & Retired & $4.3 \%$ \\
\hline & Other & $1.7 \%$ \\
\hline \multirow[t]{6}{*}{ Monthly Income * } & 12,000 to $20,000 ₹$ & $21.4 \%$ \\
\hline & 20,000 to $30,000 ₹$ & $8.5 \%$ \\
\hline & 30,000 to $40,000 ₹$ & $13.7 \%$ \\
\hline & 40,000 to $80,000 ₹$ & $21.4 \%$ \\
\hline & 80,000 to $120,000 ₹$ & $15.4 \%$ \\
\hline & more than 120,000 ₹ & $19.6 \%$ \\
\hline
\end{tabular}

* Amount is total household monthly income. Income groups are based on the modified Kuppuswamy socioeconomic scale (Mohd Saleem, 2019).

communication with farmer, price, and logistics. Figure 1 shows that the most positive aspect of direct purchasing is freshness, while the most negative aspect is the logistics involved.

Table 2. Fresh Vegetable and Fruit Purchasing Behavior Before and During Lockdown ( $N=117)$

\begin{tabular}{lcccc}
\hline & Directly from farmer & Supermarket & Market & \multicolumn{2}{c}{$\begin{array}{c}\text { Vegetable/ } \\
\text { Fruit shop }\end{array}$} & Pushcart vendor & $77.8 \%$ & $45.3 \%$ \\
\hline Before lockdown & $7.7 \%$ & $46.1 \%$ & $37.6 \%$ & $69.2 \%$ \\
\hline During lockdown & $9.4 \%$ & $31.6 \%$ & $21.4 \%$ & $40.2 \%$ \\
\hline
\end{tabular}

Table 3. Mode of Contact for Direct Purchase from Farmers Before and During Lockdown $(N=117)$

\begin{tabular}{lcccccc}
\hline & $\begin{array}{c}\text { Personal contact } \\
\text { with farmer }\end{array}$ & $\begin{array}{c}\text { Resident Welfare } \\
\text { Association }\end{array}$ & $\begin{array}{c}\text { Social } \\
\text { Club }\end{array}$ & NGO & Social Media & Apps \\
\hline Before lockdown & $4.3 \%$ & $0.8 \%$ & $1.7 \%$ & $0.8 \%$ & $1.7 \%$ & $0.8 \%$ \\
\hline During lockdown & $2.6 \%$ & $2.6 \%$ & $1.7 \%$ & $0.8 \%$ & $2.6 \%$ & $2.6 \%$ \\
\hline
\end{tabular}


Figure 1. Consumer Perspective on Positive and Negative Aspects of Direct Purchasing from Farmers $(N=117)$

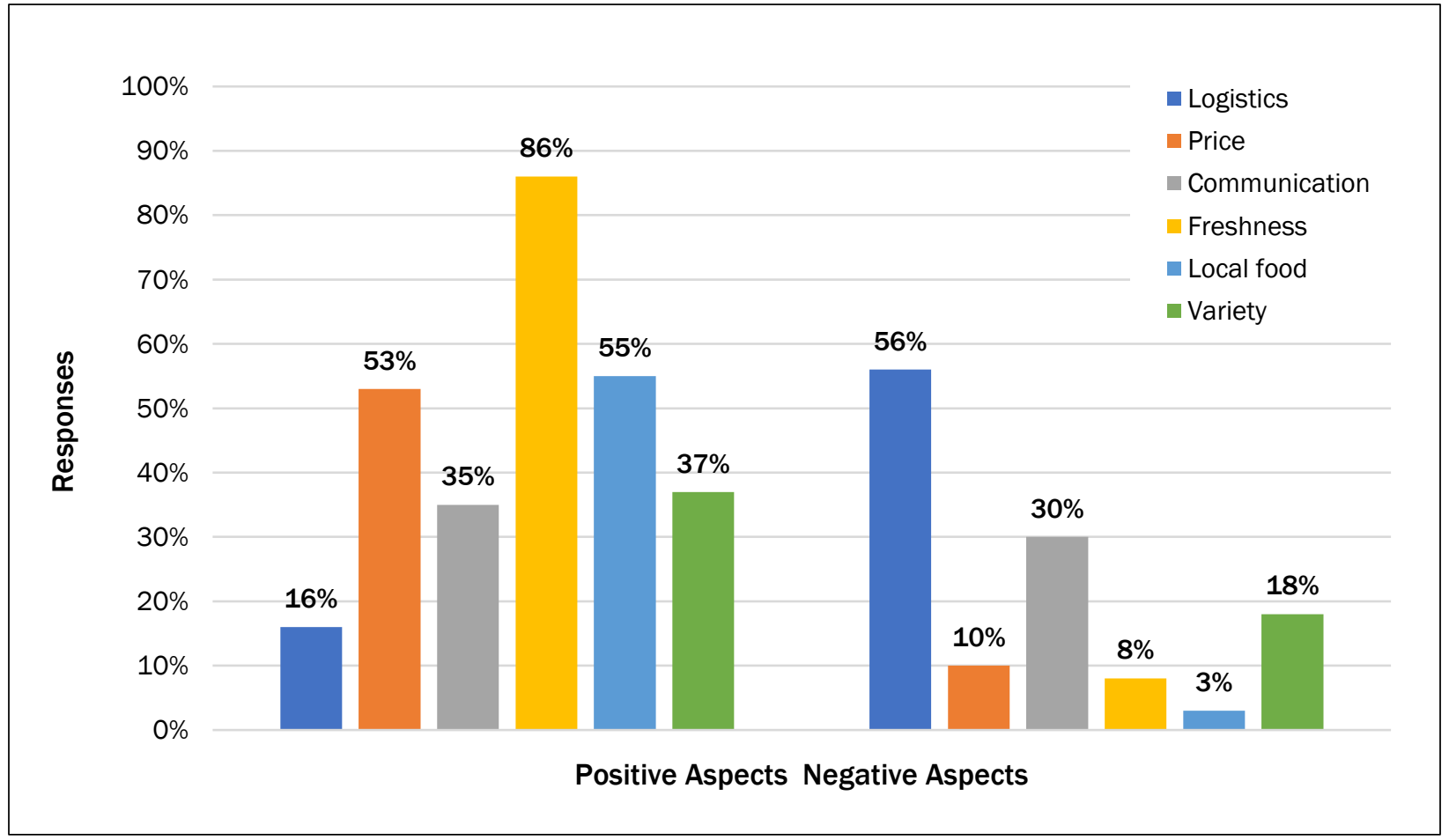

Community supported agriculture

We asked respondents if they are a member of a CSA or if they would like to be. Only three of 117 respondents are currently in a CSA. However, 45 respondents $(38 \%)$ said that they would like to join a CSA but it is not available in their area.

\section{Results of $\mathrm{RW}$ A telephone survey}

During the lockdown period, RWAs engaged with residents to assist in procuring essential goods.

Out of our sample size of 117 RWAs, 42 arranged for farmers to directly sell fruits and vegetables to residents. When asked if they knew of other RWAs arranging direct marketing of fresh fruits and vegetables, 19 responded yes and 98 responded no.

All of the following results are based on a sample size of 42 . Forty RWAs sourced vegetables directly from farmers, however none of the RWAs in our sample worked with FPOs. Two RWAs also worked with HOPCOMS to source fresh produce, while one worked closely with a street vendor, and one with a private driver. When asked how the RWA contacted farmers, $90.5 \%$ of RWAs made the contact either through family or friends. WhatsApp (42.9\%), TV (21.4\%), a government agency $(19 \%)$, and the newspaper $(7.1 \%)$ were also used to reach farmers. One RWA used a Farmer Producer app. Other options included in the survey that were not used are NGOs, social media, radio, and advertisement.

The main products sold by farmers were fruits and vegetables, including but not limited to grapes, papaya, banana, pineapple, tomatoes, chilies, onions, okra, drumstick, and eggplants. Millets, pulses, and milk were also sold, but only in four instances. None of the RWAs found the prices to be more expensive, with 36 reporting that the prices were lower, and six reporting that the prices were the same as elsewhere. Going forward, only five RWAs are motivated to continue working with farmers to facilitate direct marketing to their residents. Many are unsure, with 26 responding that it depends on circumstances. Eleven RWAs responded that they are not interested in continuing this activity, citing convenience and communication with farmers as the main hinderances. 
Results of FPO telephone survey

Telephone-based interviews were conducted with six FPOs that are registered in either Bengaluru Urban or Bengaluru Rural; five have a membership of 1,000 farmers and one has 700 farmers. Five of the six FPOs surveyed sold produce directly to consumers during the lockdown, with three FPOs saying that this was a regular marketing channel for them even before the COVID-19 pandemic. None of the FPOs offer direct home delivery. Five FPOs sold their produce by setting up a stall outside of apartment complexes and three sold through RWAs. These arrangements were organized through personal contact between FPO members and residents (two instances), government assistance (two instances), and WhatsApp (one instance). Five of the FPOs sold fruits and vegetables, with one of the FPOs also selling fresh flowers. One FPO only sold fruits. Four FPOs answered that the price received from selling through apartment complexes and RWAs was the same as through other marketing channels, while one answered that the price was lower. Delivery was done by private vehicles that were owned or rented by a farmer or the FPO. When asked if their FPO would like to continue this kind of direct marketing, three FPOs answered yes and two answered maybe, depending on the communication with RWAs and apartment complexes. Of the three FPOs that answered yes, all of them agree that direct marketing is more profitable and they are happy to communicate with consumers directly. However, none of them recognize it as a benefit that diversifies their market channels, and only one found this type of marketing convenient.

\section{Discussion}

\section{Has the COVID-19 pandemic led to a rise in direct marketing between urban consumers and local producers?}

Our results indicate that the purchase of fruits and vegetables directly from farmers increased by $1.7 \%$ during the lockdown, while purchases from supermarkets, markets, vegetable and fruit shops, and pushcart vendors all decreased (Table 2). However, because our sample is not representative, we also reviewed media reports on fresh produce sales during the lockdown. According to the media reports, small neighborhood shops experienced a boost in sales at the beginning of the lockdown, but they also struggled to maintain supplies of fresh produce because of restrictions and limited hours of operation at wholesale markets. Shop owners also had difficulties securing travel permits to reach the markets. When they were able to reach the wholesale markets, many found that the price of some vegetables had doubled or even tripled (Bharadwaj, 2020c; Gatty, 2020). Many pushcart vendors also had difficulty accessing the wholesale markets and many faced restrictions on movement (K.C., 2020). Pushcart vendors who were able to access fresh produce benefited from the lockdown because consumers preferred the convenience of shopping from their doorstep (TNN, 2020). Large supermarkets remained open, but many consumers avoided them because of concern for virus transmission due to large crowds forming at the entrance of the stores and a lack of social distancing (Gejji, 2020).

While personal contact with farmers decreased during the lockdown, the role of RWAs, social media, and the use of food shopping apps all increased as modes of contact for purchasing directly from farmers (Table 3). Despite the reported increase, the overall number of people who engaged social media to connect with farmers was low (15 of 117 respondents), and the use of food shopping apps was even lower (nine of 117 respondents). However, the potential for platforms such as WhatsApp to connect urban residents with farmers is promising, especially considering that $42.9 \%$ of RWAs used WhatsApp to connect with farmers. The way in which neighbors can combine and organize their orders for fruits and vegetables through WhatsApp groups shows great potential for both rural-urban linkages and SFSCs.

Less promising are the multitude of food shopping apps for purchasing directly from farmers. For farmers, such apps are just another middleman. We cannot explain the low usage of food shopping apps by consumers; however, we see challenges in building trust and connection with the producers through this technology.

In the media, we found abundant reports about direct marketing initiatives, from individuals 
starting Facebook groups like Farm to Fork and the Twitter handle Harvesting Farmer Network, to women's groups, NGOs, and RWAs organizing farmers to sell to their members in bulk. With headlines in national and international press like "Farm to Home Networks go into overdrive in locked down Bengaluru," "How Lockdown has helped turn 'Farm to Fork' Dream into Reality," and "Direct-selling helps Indian farmers swerve food waste under lockdown," it appeared that a revolution was happening in the food system. ${ }^{1}$ However, our data show that while these direct marketing activities did occur, they were perhaps not as widespread as reported.

Although we recognize that our sample size is small and not representative, it does include a diverse demographic and geographical base, with online survey responses coming from all areas of the city. Furthermore, we find it significant that $38 \%$ of respondents said that they would like to join a CSA. This clearly shows a level of interest and potential demand for direct marketing on the consumer side. The question is whether farmers are able and willing to engage with this demand.

\section{Can existing community organizations, specifically} $\mathrm{RW}$ As and FPOs, collaborate in neighborhoodbased direct marketing schemes?

The results of the RWA survey show that the main motivation behind direct marketing was to help farmers during the lockdown (Table 4). RWA initiatives to connect with farmers emerged in response to lockdown restrictions and fears of the coronavirus. The lack of enthusiasm among most of the RWAs surveyed to continue this form of direct marketing shows that the effort and level of engagement required to successfully facilitate direct marketing is high. We must remember that RWAs were not created explicitly for this purpose. With the opening up of offices and businesses, the effort by RWAs is likely to dissipate further as most of the members are volunteers whose primary responsibility is responding to infrastructure-related issues within their neighborhood. Nevertheless, the fact that $36 \%$ of RWAs in our survey did engage in direct marketing shows that RWAs can be an entry point for individual farmers or FPOs to reach geographically and digitally clustered consumers.

From the FPO perspective, only three of the five FPOs engaged in direct marketing are interested in continuing this type of marketing. While four out of five FPOs said that they received the same price for their produce as they would elsewhere, this is perhaps not enough profit when considering the communication and delivery costs and the total amount of produce sold. During the lockdown many farmers sold their harvest through such direct marketing opportunities in order to avoid total loss. However, as a long-term strategy, direct marketing must be profitable for them, arguably more profitable than selling through traditional marketing channels.

\section{Can the direct procurement practices of urban} consumers developed during lockdown be sustained? When asked to consider the positive and negative aspects of direct purchasing from farmers, consumers stated that the freshness of fruits and vegetables is the most positive benefit (Figure 1). They also value buying locally produced food and appreciate the lower prices resulting from direct marketing. Communication with farmers was almost evenly split between being a positive or a negative aspect. Logistics of purchasing from farmers is by far the most negative aspect of this interaction. This is indeed a challenge for both consumers and producers. For consumers, the level of engagement required to communicate with farmers and negotiate price, quantity, and delivery

\section{Table 4. Resident Welfare Association (RWA) Motivations for Engaging with Farmers for Direct Marketing $(\mathrm{N}=\mathbf{4 2})$}

\begin{tabular}{lc}
\hline Direct marketing motivations & Response=Yes \\
\hline To help farmers during lockdown & $95.2 \%$ \\
\hline To avoid leaving home & $88.1 \%$ \\
\hline Afraid to go shopping & $83.3 \%$ \\
\hline Produce would be wasted in lockdown & $50.0 \%$ \\
\hline Farmer produce is fresher & $19.0 \%$ \\
\hline Because shops were closed & $16.7 \%$ \\
\hline
\end{tabular}

\footnotetext{
${ }^{1}$ The headlines are from Citizen Matters, The Times of India, and Deutsche Welle, respectively.
} 
are all time-consuming activities. The quality of the produce and the value-added of knowing where their food comes from must adhere to a high standard for them to pursue direct purchasing (Moustier \& Renting, 2015). For producers, the logistical challenges of marketing are manifold and include availability of on-farm labor for crop management, harvest and post-harvest activities, transportation of produce, communication with buyers on quantity and quality, and ensuring a price that affords the producer an adequate profit. Therefore, in order for direct marketing activities to gain a wider consumer base, it must become more streamlined and convenient for all parties.

\section{Conclusion}

The resilience of Bengaluru's food system is apparent, not only in the steady availability of fresh foods throughout the lockdown, but also through the efforts and ingenuity of actors all along the food chain to produce, procure, distribute, and consume locally grown foods. "In the context of urban resilience, ensuring a supply of food produced as locally as possible is the key to having a stable food supply that can be distributed to an urban population as quickly as possible-especially critical in cases of extreme weather events or other disasters" (Ballamingie et al., 2020, p. 234). The COVID-19 pandemic certainly falls under the category of other disasters, and this headline from The Hindu newspaper, "Meet India's inspiring farmers who pivot, adapt, and keep supplying fresh produce during the lockdowns", captures the coordinated resilience perfectly.

It is apparent that the lockdown created a situation where consumers and producers are seeking one another out, albeit for different reasons. While consumers are mostly concerned with their own personal health and with helping farmers through these difficult times, farmers are focused on minimizing losses. Farmers are willing to sell directly to consumers, and consumers value the produce from farmers, but the logistics involved are a deterrent. There are many direct marketing models that can be adapted to meet the local context, however food policies that support such activities must be feasible for smallholder farmers.

RWAs have access to geographically based, and in many cases digitally-connected, consumer groups who can collectively constitute a profitable target for FPOs. The number of FPOs is predicted to increase due to the COVID-19 pandemic and favorable GOI legislation. Linking FPOs directly with consumer groups enables FPOs to market large quantities of produce, thus improving the logistical and economic benefits for both producers and consumers. Instead of home delivery, the pop-up farmers market (for example, selling from a vehicle or a temporary stall) in a neighborhood or in front of an apartment complex is a successful approach to direct marketing.

A larger study of consumer, RWA, and FPO direct marketing activities is needed to more accurately measure the level of interest in direct marketing. Our study is limited in scope and, because we were unable to contact $49 \%$ of the RWAs in our sample, we can only draw limited conclusions. Nevertheless, we find the network of RWAs throughout the city to be a promising target for FPOs to reach consumers and diversify their marketing activities, thereby strengthening rural-urban linkages and making the city region food system of Bengaluru more sustainable and resilient.

\section{Acknowledgments}

We would like to thank Dr. Shilpa Yatnatti, Elena Maria Wenninger, Raksha Sharma C.M., Dr. Daniel Wyss, Peter Shapland, and Frederik Sagemüller for their contributions to this research project and publication.

\section{References}

Abhishek, Bhamoriya, V., Gupta, P., Kaushik, M., Kishore, A., Kumar, R., Sharma, A., \& Verma, S. (2020). India’s food system in the time of COVID-19. Economic \& Political WEEKLY, 55(15), 12-14. Retrieved from https://www.epw.in/journal/2020/15/commentary/indias-food-system-time-covid-19.html

Abraham, M.-R. (2020, May 27). Direct-selling helps Indian farmers swerve food waste under lockdown. Deutsche Welle $(D W)$. Retrieved from https://p.dw.com/p/3cjMI 
Aggarwal, M. (2020, May 12). An online network emerges during the lockdown connecting farmers directly with customers. Mongabay. Retrieved from https://india.mongabay.com/2020/05/an-online-network-emerges-duringthe-lockdown-connecting-farmers-directly-with-customers/

Babu, S. C., \& Dassani, V. (2020, July 16). COVID-19-induced policy reforms in India: Overcoming implementation challenges. Inter Press Service News Agency. Retrieved from http:/ / www.ipsnews.net/2020/07/covid-19-induced-policy-reforms-india-overcoming-implementation-challenges/

Balaji, N. S. (2020, August 9). Are the new agriculture ordinances an extension of the WTO's Agenda? The Wire. Retrieved from https://thewire.in/agriculture/agriculture-ordinance-wto-india-farmers-msp-apmc

Ballamingie, P., Blay-Palmer, A. D., Knezevic, I., Lacerda, A. E. B., Nimmo, E. R., Stahlbrand, L., \& Ayalon, R. (2020). Integrating a food systems lens into discussions of urban resilience: A policy analysis. Journal of Agriculture, Food Systems, and Community Development, 9(3), 1-17. https://doi.org/10.5304/jafscd.2020.093.021

Bengaluru Bureau (2020, March 24). Scramble for groceries as supermarkets close and police crack down on vegetable vendors. The Hindu. Retrieved from https://www.thehindu.com/news/cities/bangalore/scramble-for-groceries-assupermarkets-close-and-police-crack-down-on-vegetable-vendors/article31155067.ece

Bengaluru Governance Observatory. (2020). RWA central. Retrieved from http://bengaluru.staging.mapunity.com/Government

Berdegué, J. A., Proctor, F. J., \& Cazzuffi, C. (2014). Inclusive rural-urban linkages (Working Paper Series No. 123). Working Group: Development with Territorial Cohesion. Retrieved from RIMISP website: https://rimisp.org/wp-content/files mf/1431869344123InclusiveRural UrbanLinkages edited.pdf

Bharadwaj, K. V. A. (2020a, March 21). Covid-19: Veggie prices shoot up over short supply and panic buying. The Hindu. Retrieved from https://www.thehindu.com/news/cities/bangalore/covid-19-veggie-prices-shoot-up-over-shortsupply-and-panic-buying/article31130321.ece

Bharadwaj, K. V. A. (2020b, March 29). Yeshwantpur APMC yard to function for four hours three days a week. The Hindu. Retrieved from https://www.thehindu.com/news/cities/bangalore/yeshwantpur-apmc-yard-to-functionfor-four-hours-three-days-a-week/article31201476.ece

Bharadwaj, K. V. A. (2020c, March 31). No lockdown for them: Friendly neighbourhood grocer comes to the rescue. The Hindu. Retrieved from https://www.thehindu.com/news/cities/bangalore/no-lockdown-for-them-friendlyneighbourhood-grocer-comes-to-the-rescue/article31221323.ece

Bhatt, N. (2020, July 6). Farmers' markets go hi-tech: How online sales are saving Indian farmers. The Guardian. Retrieved from https://www.theguardian.com/global-development/2020/jul/06/farmers-markets-go-hi-tech-howonline-sales-are-saving-indian-farmers

Bisht, I. S., Rana, J. C., \& Pal Ahlawat, S. (2020). The future of smallholder farming in India: Some sustainability considerations. Sustainability, 12(9), 3751. https://doi.org/10.3390/su12093751

Biswas, P. (2020, April 10). Explained: Direct farm-to-kitchen delivery provides relief, holds promise. The Indian Express. Retrieved from https://indianexpress.com/article/explained/explained-direct-farm-to-kitchen-relief-with-promise-6355505/

Blay-Palmer, A., Santini, G., Dubbeling, M., Renting, H., Taguchi, M., \& Giordano, T. (2018). Validating the city region food system approach: Enacting inclusive, transformational city region food systems. Sustainability, 10(5), 1680. https://doi.org/10.3390/su10051680

Bruhat Bengaluru Mahanagara Palike [BBMP]. (2016). RWA \& Suchimitra. Retrieved from http://218.248.45.172:81/en/web/guest/rwa-suchimitra

Carey, J., \& Dubbeling, M. (2017). City region food system indicator framework. Retrieved from RUAF Foundation website: https://ruaf.org/document/city-region-food-system-indicator-framework/

Ceballos, F., Kannan, S., \& Kramer, B. (2020). Impacts of a national lockdown on smallholder farmers' income and food security: Empirical evidence from two states in India. World Development, 136, 105069. https://doi.org/10.1016/j.worlddev.2020.105069

Chand, R. (2012). Development policies and agricultural markets. Economic \& Political WEEKLY, 47(52), 53-63. Retrieved from http://www.jstor.com/stable/41720551 
Chintala, G. R., \& Mani, G. (2020, July 30). New agri-reforms: Farmers' collectives set to gain the most. Financial Express. Retrieved from https://www.financialexpress.com/opinion/new-agri-reforms-farmers-collectives-set-to-gain-the-most/2039242/

Deepika, K. C. (2020, April 20). Street vendors struggle to stay afloat. The Hindu. Retrieved from https://www.thehindu.com/news/cities/bangalore/street-vendors-struggle-to-stay-afloat/article31387525.ece

Devy, M. S., \& Casiker, C. V. (2020, September 21). Can Bengaluru pave way for urban farming? Deccan Herald. Retrieved from https://www.deccanherald.com/opinion/in-perspective/can-bengaluru-pave-way-for-urban-farming-890612.html

Dubbeling, M., Renting, H., \& Hoekstra, F. (2015, May). Urban agriculture magazine: City region food systems. (29). Retrieved from RUAF website: https://ruaf.org/document/urban-agriculture-magazine-no-29-city-region-food-systems/

Erler, M., \& Dittrich, C. (2020). Middle class, tradition and the desi-realm-Discourses of alternative food networks in Bengaluru, India. Sustainability, 12(7), 2741. https://doi.org/10.3390/su12072741

Fielding, N. G., Lee, R. M., \& Blank, G. (Eds.) (2016). The SAGE bandbook of online research Methods (2nd ed.). Los Angeles, CA: SAGE Publications. https://doi.org/10.4135/9781473957992

Food and Agriculture Organization [FAO]. (2018). Sustainable food systems: Concept and framework. Retrieved from The Food and Agriculture Organization of the United Nations website: http://www.fao.org/3/ca2079en/CA2079EN.pdf

Frayer, L., \& Pathak, S. (2020, March 31). Coronavirus lockdown sends migrant workers on a long and risky trip home. NPR. Retrieved from https://www.npr.org/sections/goatsandsoda/2020/03/31/822642382/coronaviruslockdown-sends-migrant-workers-on-a-long-and-risky-trip-home?t=1600265017726

Gatty, H. R. (2020, May 5). Will your neighborhood grocery store recover from COVID lockdown? Citizen Matters. Retrieved from https://bengaluru.citizenmatters.in/neighbourhood-retail-store-economic-recovery-lockdownsupply-chain-footfall-home-delivery-45108

Gejji, A. (2020, April 11). Karnataka: Why shoppers are swearing by kirana stores. Times of India. Retrieved from https://timesofindia.indiatimes.com/city/bengaluru/karnataka-why-shoppers-are-swearing-by-kiranastores/articleshow/75090039.cms

Gettleman, J., \& Schultz, K. (2020, March 24). Modi orders 3-week total lockdown for all 1.3 billion Indians. The New York. Times. Retrieved from https://www.nytimes.com/2020/03/24/world/asia/india-coronavirus-lockdown.html

Govardan, D. (2020, May 16). How lockdown has helped turn 'farm to fork' dream into reality. Times of India. Retrieved from https://timesofindia.indiatimes.com/india/how-lockdown-has-helped-turn-farm-to-fork-dream-intoreality/articleshow/75488361.cms

Government of India. (2019). Agricultural statistics at a glance 2018. Retrieved from Ministry of Agriculture \& Farmers Welfare website: https://eands.dacnet.nic.in/PDF/Agricultural\%20Statistics $\% 20 a t \% 20 a \% 20$ Glance $\% 202018$.pdf

Government of Karnataka. (n.d.). Bengaluru urban district. Retrieved August 24, 2020, from https://bengaluruurban.nic.in/en/

Harriss, J. (2010). 'Participation' and contestation in the governance of Indian cities (Simons Papers in Security and Development No. 3). Retrieved from School for International Studies, Simon Fraser University website: https://summit.sfu.ca/item/14834

Jennings, S., Cottee, J., Curtis, T., \& Miller, S. (2015). Food in an urbanised world: The role of city region food systems in resilience and sustainable development. Retrieved from 3 Keel website: www.fao.org/fileadmin/templates/agphome/documents/horticulture/crfs/foodurbanized.pdf

Joshi, S. (2020, May 28). How social media is helping farmers take produce straight to kitchens. Times of India. Retrieved from https:/ / timesofindia.indiatimes.com/india/how-social-media-is-helping-farmers-take-produce-straight-tokitchens/articleshow/75694230.cms

K. R., J. (2020a, April 28). Fresh from farm, directly to home during COVID-19 lockdown. The Hindu. Retrieved from https://www.thehindu.com/news/cities/bangalore/fresh-from-farm-directly-to-home-during-covid-19lockdown/article31456667.ece 
K. R., J. (2020b, April 14). Home delivery system in four Assembly constituencies gets positive response. The Hindu. Retrieved from https://www.thehindu.com/news/cities/bangalore/home-delivery-system-in-four-assemblyconstituencies-gets-positive-response/article31341592.ece

Kappan, R. (2020, May 19). 'Save the Farmer' project door-delivers 22 MT of fresh farm produce. Deccan Herald. Retrieved from https://www.deccanherald.com/city/life-in-bengaluru/save-the-farmer-project-door-delivers-22mt-of-fresh-farm-produce-839265.html

Karelia, G. (2020, April 15). Bengaluru initiative delivers fresh veggies directly from farms to 700+ families. The Better India. Retrieved from https://www.thebetterindia.com/223758/coronavirus-lockdown-bengaluru-home-deliveryvegetables-farmers-contact-covid19-india-gop94/

Krishi Jagran. (n.d.). Karnataka FPO's. Retrieved in 2020 from https://krishijagran.com/list-of-fpo/karnataka-fpos/

Kumar, A., Padhee, A. K., \& Kumar, S. (2020). How Indian agriculture should change after COVID-19. Food Security, 12, 837-840. https://doi.org/10.1007/s12571-020-01063-6

Kumar, B. S. S. (2020a, April 6). UAS-B Alumni Association steps in to help grape farmers. The Hindu. Retrieved from https://www.thehindu.com/news/national/karnataka/uas-b-alumni-association-steps-in-to-help-grapefarmers/article31274795.ece

Kumar, B. S. S. (2020b, April 22). Several people take to terrace gardening to beat lockdown boredom. The Hindu. Retrieved from https://www.thehindu.com/news/cities/bangalore/several-people-take-to-terrace-gardening-tobeat-lockdown-boredom/article31406736.ece

Kumar, D. (2020). Half a million COVID-19 cases in India: How we got to where we are. The Wire. Retrieved from https://thewire.in/covid-19-india-timeline

Mahadevia, D., Bhatia, N., \& Bhatt, B. (2016). Decentralized governance or passing the buck: The case of resident welfare associations at resettlement sites, Ahmedabad, India. Environment and Urbanization, 28(1), 294-307. https://doi.org/10.1177/0956247815613688

Mint. (2020, July 21). Govt notifies two Ordinances for barrier-free farm trading. Retrieved from https://www.livemint.com/news/india/govt-notifies-two-ordinances-for-barrier-free-farm-trading11595330924061.html

Mishra, S. V., Gayen, A., \& Haque, S. M. (2020). Covid-19 and urban vulnerability in India. Habitat International, 103, 102230. https://doi.org/10.1016/i.habitatint.2020.102230

Mohd Saleem, S. (2019). Modified Kuppuswamy socioeconomic scale updated for the year 2019. Indian Journal of Forensic and Community Medicine, 6(1), 1-3. https://doi.org/10.18231/2394-6776.2019.0001

Moore, O., McCarthy, O., Byrne, N., \& Ward, M. (2014). Reflexive resilience and community supported agriculture: The case that emerged from a place. Journal of Agriculture, Food Systems, and Community Development, 4(3), 1-17. https://doi.org/10.5304/jafscd.2014.043.007

Moragues-Faus, A., Marsden, T., Adlerová, B., \& Hausmanová, T. (2020). Building diverse, distributive, and territorialized agrifood economies to deliver sustainability and food security. Economic Geography, 96(3), 219-243. https://doi.org/10.1080/00130095.2020.1749047

Moustier, P., \& Renting, H. (2015). Urban agriculture and short chain food marketing in developing countries. In H. de Zeeuw \& P. Drechsel (Eds.), Cities and agriculture: developing resilient urban food systems (pp. 121-138). Abingdon: Routledge.

Muggah, R., \& Florida, R. (2020, May 27). COVID-19 will hit the developing world's cities hardest. Here's why. World Economic Forum. Retrieved from https://www.weforum.org/agenda/2020/05/covid-19-will-hit-the-developingworlds-cities-hardest-heres-why/

National Bank for Agriculture and Rural Development [NABARD]. (2020). NABARD portal on farmer producers' organizations (Promoted under PRODUCE Fund). Retrieved from https://nabfpo.in/images/staticFPO.html

Nainar, N. (2020, April 9). During the lockdown, this Bengaluru company is using an app to bring farm-fresh produce to seven cities. The Hindu. Retrieved from https://www.thehindu.com/sci-tech/agriculture/fresh-produce-isdelivered-in-six-cities-using-data-analytics-and-technology-by-ninjacart/article31301436.ece

Narayanan, S., \& Saha, S. (2020). Urban food markets and the lockdown in India. https://doi.org/10.2139/ssrn.3599102 
Neti, A., Govil, R., \& Rao, M. R. (2019). Farmer producer companies in India: Demystifying the numbers. Review of Agrarian Studies, 9(2), 92-113. Retrieved from http://ras.org.in/fc5e6f86c86e8548e3eb17f4ec8fbc9f

Nikam, V., \& Kale, R. (2020, April 11). Blog 110-Unshackling farmer producer organizations from the COVID-19 lockdown [Blog post]. Retrieved from https://www.aesanetwork.org/blog-110-unshackling-farmer-producer-organisations-from-the-covid-19-lockdown/

Proctor, F. J., \& Berdegué, J. A. (2016, June). Food systems at the rural urban interface (Working Paper Series No. 194). Retrieved from RIMISP website: https://webnueva.rimisp.org/ingles/food-systems-at-the-rural-urban-interface/

Raj, A. (2020, April 1). COVID-19: Karnataka farmers dump produce as supply chain snaps. The Quint. Retrieved from https://www.thequint.com/coronavirus/covid-19-effect-karnataka-farmers-dump-produce-as-supply-chain-snaps

Rao, B. G. (2020, April 24). Farm to Home Networks go into overdrive in locked down Bengaluru. Citizen Matters. Retrieved from https://bengaluru.citizenmatters.in/covid19-lockdown-bengaluru-farm-to-home-network-door-delivery-44556

Sami, N., \& Surie, A. (2017). The urban food system of Bangalore, India (Hungry Cities Partnership Report No. 5). Retrieved from Hungry Cities Partnership website: https://hungrycities.net/publication/hcp-report-no-5-urban-food-system-bangalore-india/

Small Farmers' Agri-Business Consortium [SFAC]. (2016). List of FPO statewise. Retrieved from http://sfacindia.com/List-of-FPO-Statewise.aspx

SFAC. (2020). Covid-19 lockdown agri news bulletin. SFAC activities undertaken for FPOs during Covid-19 period in the country. Retrieved from http://sfacindia.com/covid.aspx

Special Correspondent. (2020a, April 15). City-wide home delivery helpline soon: BBMP chief. The Hindu. Retrieved from https://www.thehindu.com/news/cities/bangalore/city-wide-home-delivery-helpline-soon-bbmpchief/article31349200.ece

Special Correspondent. (2020b, May 2). Ninjacart to link farmers to end users. The Hindu. Retrieved from https://www.thehindu.com/news/national/karnataka/ninjacart-to-link-farmers-to-end-users/article31491708.ece

Special Correspondent. (2020c, May 10). 'FPOs can help make farming profitable.' The Hindu. Retrieved from https://www.thehindu.com/news/national/karnataka/fpos-can-help-make-farming-profitable/article31552595.ece

Sukhwani, V., Deshkar, S., \& Shaw, R. (2020). Covid-19 lockdown, food systems and urban-rural partnership: Case of Nagpur, India. International Journal of Environmental Research and Public Health, 17(16), 5710. https://doi.org/10.3390/ijerph17165710

TNN. (2020, April 16). Pushcart vendors make hay while coronavirus sends people indoors. Times of India. Retrieved from https://timesofindia.indiatimes.com/city/coimbatore/pushcart-vendors-make-hay-while-coronavirus-sendspeople-indoors/articleshow/75169806.cms

Trebbin, A. (2014). Linking small farmers to modern retail through producer organizations - Experiences with producer companies in India. Food Policy, 45, 35-44. https://doi.org/10.1016/j.foodpol.2013.12.007

Trebbin, A., \& Hassler, M. (2012). Farmers' producer companies in India: A new concept for collective action? Environment and Planning A: Economy and Space, 44(2), 411-427. https://doi.org/10.1068/a44143

Wangchuk, R. N. (2020, April 27). 4 initiatives giving real hope to farmers hit hardest by the corona lockdown. The Better India. Retrieved from https://www.thebetterindia.com/224696/coronavirus-covid19-harvesting-buy-direct-farmersnetwork-twitter-satara-bengaluru-india-nor41/

World Population Review. (2021). Bangalore population 2021. Retrieved from https://worldpopulationreview.com/world-cities/bangalore-population

Worstell, J., \& Green, J. (2017). Eight qualities of resilient food systems: Toward a sustainability/resilience index. Journal of Agriculture, Food Systems, and Community Development, 7(3), 1-19. https://doi.org/10.5304/jafscd.2017.073.001 


\section{Appendix A. List of Facebook Groups Targeted in Online Survey}

1. Bengaluru Foodies Club

2. Vidyaranyapura Citizens Welfare Association

3. Bangalore Foodies Club

4. Bangalore Foodies

5. Covid-19 Farm to Fork

6. Put me in Touch with Bangalore

7. Terrace Gardening

8. Organic Terrace Gardening Bangalore

9. Bangalore South Organic Terrace Gardening

10. Marathahalli

11. Organic Terrace Gardening

12. Terrace Gardening Bengaluru 